\title{
The Touch of Intelligence
}

\section{Dotyk inteligencjii}

\begin{abstract}
I have yet to be persuaded that what arts therapists are doing with their clients either actually counts as art-rather than an applied form of occupational therapy-or seems likely to have any long-term effect on easing their suffering, other than by distraction and temporary companionship. I don't for a moment doubt the relevance of the arts, properly so called, for individual and collective wellbeing-one of the aims of this paper is to spell out what that might mean-but an art practice structured around the conventions of psychoanalysis seems to me entirely mistaken because, as a basis of legitimacy, it favours rationality and modelling over feeling and making good things. Rational, analytical ways of knowing are a direct contradiction to the intuitive and imaginative procedures of art, where touch rather than talk does all the work. The arts offer to effect change in the patient from within rather than from without, via empathetic attunement between the therapist and the patient rather by than argument and persuasion on the one hand or compliance on the other.
\end{abstract}

\section{ABSTRAKT}

Nie jestem do końca przekonany, że to, co zwykle arteterapeuci robiq ze swoimi klientami jest rzeczywiście sztukq, a nie pewnq formq terapii zajęciowej. Również nie mam pewności, czy te działania mogq mieć

\section{KEYWORDS}

arts education, arts therapy, affective intelligence, imagination, beauty, metamorphosis

\section{StOWA KLUCZOWE}

edukacja artystyczna, arteterapia,

afektywna inteligencja, wyobraźnia, piękno, przemiana (metamorfoza)

SPI Vol. 24, 2021/4

ISSN 2450-5358

e-ISSN 2450-5366

DOI: 10.12775/SPI.2021.4.003

Submitted: 28.09.2021 Accepted: 22.11.2021

Articles and dissertations 
jakikolwiek długotrwały wpływ na złagodzenie ich cierpienia, inny niż tylko ten, który osiqgamy poprzez zwykłe przesunięcie uwagi i zapewnienie chwilowego towarzystwa $w$ działaniu. Przy czym ani na chwilę nie zwątpiłem w istotny zwiqzek sztuki z indywidualnym i zbiorowym dobrostanem, z zastrzeżeniem, że mówimy o tych formach i akływnościach, które zostały sztukq nazwane właściwie. Jednym z celów tego tekstu jest wyartykułowanie, jak można rozumieć to znaczenie. Praktyka arteterapeutyczna zbudowana wokół konwencji, którymi posługuje się psychoanaliza, wydaje mi się całkowicie błędna, ponieważ u legitymizujących ją podstaw leży racjonalność i modelowanie, które sq przedkładane nad odczuwanie i tworzenie dobrych artystycznych form. Racjonalne, analityczne sposoby poznawania widzę jako całkowite zaprzeczenie intuicyjnych i wyobrażeniowych procedur poznawania w sztuce, gdzie - jak jestem przekonany - dotyk (ang. touch), a nie rozmowa, ma znaczenie terapeutyczne. Sztuka oferuje zmianę w pacjencie raczej w działaniach prowadzonych "od wewnqtrz" niż "z zewnqtrz" procesów twórczych. Jest to możliwe dzięki empatycznemu zestrojeniu terapeuty z pacjentem, a nie dzięki argumentom i perswazjom z jednej strony, a posłuszeństwu z drugiej.

"A poem should not mean

But be."

(Archibald MacLeish)

\section{Foreword}

I write this piece as an arts teacher rather than an arts therapist. As a teacher my purpose has been relatively simple: to share the pleasure the arts have brought me with my students. We have made art together, written poetry, made pictures, made films and created music, theatrical performances and dances. We have read and discussed books, visited exhibitions, attended musical gigs and concerts. I have judged my success in terms of the happiness we have shared and the enlightenment they have received. The aims of the therapist strike me as daunting by comparison: nothing less than restoring someone's mental and emotional wellbeing. When I moved from school teaching to teacher training and then on to teaching and research at a university, I found myself drawn into a political debate 
as to the usefulness of the arts. I was forced to answer questions about the purpose of the arts in education at a time of serious economic difficulty, when not only government ministers but also parents and the students themselves were seeing schooling more as a preparation for a life of work than for life of time. As a result, I became a voluble and enthusiastic apologist for the psychological and social benefits of the expressivist tradition in the arts and the transferrable skills of creativity. It no longer cut any ice with my masters simply to talk about pleasure, happiness and quality of life.

It's now more than 20 years since I retired, and although I am prepared to take up the cudgels against the philistines and argue them into a corner, my heart is no longer in it. I've taken to making pictures myself and am once again content simply to see the arts as a source of profound pleasure, rather than fuss too much about the reasonableness of what I'm doing. My happiness does not depend upon my art, but my making adds significantly to its sum. What is more, I have begun to have doubts about my life as an apologist-it now smacks for me too much of the evangelist, and that makes me uncomfortable. Art making has opened a door for me, and I know that I'm at my happiest when I can open a door for someone else. If the arts therapist could be happy with that too, then we might get along together pretty well.

To become a good doorman it helps to have a theory of doors: to know something about their uses, the variety of shapes they take, the materials of which they are constructed and the way they perform at their best. Experience has taught me how and when to open doors for my students and how and when to keep them closed. Where they needed schooling, I schooled them; where they needed to run wild, I let them-being careful to leave the door open until they were all safely back home under my wing again. When they smiled, I smiled too. When they were downcast or confused, I sought them out - making sure to shut the door behind me so we should not be disturbed. What I have to say here will be in the same spirit: if I can open a door for you, I shall be glad. Just don't ask me to find some impressive reason for doing so. 


\section{The Gospel of Touch}

When my colleague Robert Witkin published his book The Intelligence of Feeling (1974), the research project we were working on had no brief to enquire into the application of the arts to health. We were focussed on accounting for the perceived poor performance of arts teachers in English secondary schools at the time and on offering a conceptual framework to underpin and promote good practice. Nonetheless, central to our study was the firm attachment of arts teachers to the notion that the value of the arts for children in school lay essentially in the scope they give for self-expression—understood as both a psychological imperative and a political right.

Feeling is to be distinguished firmly from emotion here: emotions operate within the field of action, of what Wordsworth called the world of "getting and spending," of calculation: emotions trigger reactions. Feelings, on the other hand, articulate desire: feelings function within the reflexive world of contemplation. Her mother's emotions are part of an alien universe the infant must learn to acclimatize to, whereas the feel of her intelligence towards her, and towards life more generally, will shape her prospects of finding happiness later in life. Tactus is the feel of intelligence-in the musician as well as in the mother. Tactus in music is associated with a rudimentary and yet exquisitely sensitive form of rhythmical attunement, making its appearance for the first time, so I'm told, during the period of the Renaissance.

In due course it was replaced by mensuration, the counting of beats and the imposition of bars. Regulation rather than feeling came to dominate the Western classical musical tradition and the metronome became its symbol: time was beaten into submission by the time-keepers-a consequence perhaps of the advent of expansive orchestration. Good enough mothering cannot be done by the book; no more should rhythm be confused with beat: both Schubert and the Beatles (despite the name) understood that. Music properly so called is a feeling of mutuality in one's bones, not a didactic or manipulative medium. The maestro imposes their will upon the music-makers: the genuine musician is always the music's begetter, not simply its performer. The tactus is not the "pulse" or "heartbeat" of a musical piece-as is so often said. On the contrary, it is the "breath" - the steady expansion and contraction of the breast, the élan vital. Tactus 
is rhythm, whilst mensuration is beat; tactus is Keiros, mensuration is Chronos; tactus is feeling, mensuration is counting.

The gospel of touch makes music and the arts quintessentially human activities and rescues them from the hegemony of the machine. The so-called tactus hand beautifully illustrates how the tactus works. The tactus hand of the conductor rises and falls with the swell of the piece, marking its steady breathing, timing its flow to the periods of human speech. I remember my joy at being inducted into the periodic phrasing of psalm singing. While I remain a firm fan of Hymns Ancient and Modern, the Psalms offer something truly sublime: the rise and fall of the human breast in joy, in grief, in repose. When the Decani take the down beat, the Cantoris respond with the upbeat: Gravity flowers into Grace, response answers question in an antiphonal dance of finely attuned reflexivity.

\section{Imagination}

A poem should be equal to:

Not true.

For all the history of grief

An empty doorway and a maple leaf.

For love

The leaning grasses and two lights above the sea-

A poem should not mean

But be.

(Archibald MacLeish, from Arts Poetica 1926)

Should a poem not "mean"? For sure it should "be.”The American poet (1892-1982) is claiming a special status for poetry-as against other forms of linguistic expression. Poems impress us, not by their messages but by their uncanny sense of presence (R.P. Armstrong's "affecting presence"). If poems may be said to "mean" anything, then the meaning is in the feeling they give us that we are in their presence: in the presence of a life form, of an active (interactive) intelligence at work, with some kind of intentionality towards or intensity of focus upon us. Art confronts us with the force of truth. To the 
"meaning" and "being" of a work of art I attach Simone Weil's coupling of Gravity and Grace, Aristotle's coupling of Pity and Fear and the traditional Greek coupling for any account of art (adopted by the sculptor Eric Gill) of poiesis and techne. The $19^{\text {th }}$-century English Romantic poet Samuel Taylor Coleridge similarly divided the efficacy of formative imagination between resolution/integration (Primary) and dissolution/disintegration (Secondary) in formulating his theory of what he called the creative esemplastic power. Implicit within this duality is the principle of reflexivity, and it is the felt experience of this reciprocal motion within the formative mind and the resistant medium that constitutes the feel of feeling, performing intelligently.

Where Gravity is Force, Grace is Form; together they account for the singular impact of art, properly called the Impact of the Beautiful. Implicit within the notion of Gravity is the idea-indeed the presence- of Death. The Flamenco quality of Duende (Lorca) catches the tremor of its mortal seriousness exactly. When we claim the accolade of beauty for a poem it will be grounded, for all its lightness of being, in the gravitas of mortality: beauty has death at its core, which is why it brings tears to our eyes. As the Welsh poet Dylan Thomas put it in his poem about childhood, "Time held me green and dying/ Though I sang in my chains like the sea." Gravity, if not illuminated by Grace, is mere solemnity-beauty requires its alleviation, its tempering, by the eloquence of its presentation. Whether we are looking at a cave painting or a Rothko, we are charmed and moved by the correlation between feeling and form. Grace alone is mere frivolity, mere facility. This is the distinction made by the philosopher R.G. Collingwood: between "art properly so called" and applied or "pseudo" art.

MacLeish was arguing for the spiritual (élan vital) rather than the formal charms of art. Every proper essay of art making and performance is an evocation of presentiment (duende) leavened by love, of feeling enlightened by form, such that when the reflexive correlation between the two (Gravity and Grace) is perfect we cannot but be reduced to tears. And who is to say whether the tears be of grief or joy? Who knows what they "mean"? The reconciliation of Gravity with Grace happens within the liminal space between the making and appreciation of art: the space Winnicott described as "potential," i.e. as available to consciousness but reserved. The space of art is the space of the transitional object (Winnicott again): the work of art, in 
reconciling Gravity with Grace, meaning with delight, is the rite of passage for the maker to a new quality of being, a new way of seeing. Implicit in every work of art, properly so called, is the principle of adaptation, of change- a process I have tried to represent in my Syncretic Model of Creativity (Ross 2011). Within every work of art there is a conversation going on between the noumenal and the phenomenal.

\section{Powerful Medicine}

Art is powerful medicine-taking a sweetener with it won't help it down. It has the power (like love and rage) to blow you away. Stendhal, saturated in Rome, ended up in hospital, sick to death of beauty. Others have died in the quest. For most of us it is a purgative of sorts, both fascinating and terrible, graceful and grave, more searching of our integrity than the keenest surgeon's knife, offering a benchmark of truth we feel compelled to match with our own. And the force is in the compulsion: we cannot avoid the question asked of us by a proper work of art: Are you good enough to live with my terrifying and serene integrity? Facing the truth is as risky as facing the Gorgon and can only be done askance. Art is the image in Perseus's shield.

Once in the hunt there is no turning back; there is suffering to be done, there are doubts and misgivings to be faced, courage and resolve to be tested. The agon cannot be ducked. My point is-real art is not for the immature or the unstable. The child plays at art just like he or she plays at everything else. Art proper is biologically, mentally, emotionally and practically beyond them because they have yet to cross the threshold of adulthood, the full consciousness of mortality. That threshold is daunting, painful, wracked — and cannot be dodged. Child art suddenly falters and fails its maker: a new language is needed to interrogate the new experiences of adolescence. The language of reflexivity in which the subject does not simply assimilate the world to their own agenda, but learns to cherish the world as different-as a partner, a correspondent, one's match. I am known/loved, therefore I am. Known as two lovers know one another, i.e., in intimate reflexivity.

Becoming an adult, we find that the old ways of childhood will not do this for us and doing this is the only way now. And so, the shift from reactivity to reflexivity: the language of love for the knowing of 
love in a world in which time is running out, where the business of childhood is to ground the subject firmly in the real world-without which the potential of their entire adult future along with their capacity for mature, adult relationships is compromized. The New Angel of this new world is destined to wrestle with us all the way to death's door. If you are unsure of the ground beneath your feet, of your capacity to recover your balance rather than trip over all the time, you are not yet ready, it will not be safe for you to try your hand at art. As with the athlete, the aesthete must be exceptionally fit and technically talented to survive. Art, like sport, is for heroes. Not gods, but heroes, i.e. fellow mortals. The challenge for the teacher and the therapist is simply this: Are you good enough to be with the other in the struggle with their angel? Can you teach them to match Gravity with Grace?

\section{Gravity and Grace}

What I want to say now is pure speculation: I can cite no authorities in support (though they might be there) and I offer no evidence (though again it might be there). I offer simply what seems to me to be a possible rationale supporting the therapeutic role of the arts in addressing issues of mental health. Mental illnesses impair the practical, relational efficacy of the subject. Therapeutic interventions attempt to address and remedy these malfunctions to improve the subject's quality of life. I want to suggest that many affected subjects might be suffering from a disordered imagination.

If the function of imagination is to transform the radiant energy of the élan vital into creative power, when this capability is lost or impaired then there is a catastrophic disconnect (uncoupling) of Gravity from Grace. These two impulses are no longer able to interact to foster and nourish meaningful behaviour. The sense of personal meaning is jeopardized and has a knock-on effect upon social meaning. Their heart is not in what they do-their sense of soulfulness, of personal integrity, is fractured. Without a functioning transformer (imagination) there can be no hope of empowerment. For sufferers whose illness has its roots in environmental and experiential trauma there will be an insupportable burden of grief. For those whose sense of independence and self-sufficiency has failed to mature, there will 
be episodes of intolerable anxiety and frustration. The development of mental integrity will be blocked in both these cases, and this will impede the healthy emergence of their creative powers of integrating and transforming experience into higher levels of imaginative functioning. Meanwhile, their unhinged imagination will be playing all sorts of cruel tricks on them and their hope of happiness will be lost.

How to reset a disordered imagination? How to realign the sufferer's capacity to order their lives with the potential to re-create themselves - and so, to adapt to a changing world? How to deal with their creative block? It seems to me entirely possible that by engaging sufferers in serious, intrinsically satisfying art making, performance and reception, they can be inducted into the reflexive processes that constitute the creativity of the intelligence of feeling. By learning to work with the transformative esemplastic power of a properly functioning imagination, within the safe, contemplative space of art, they will begin to directly experience the sense of personal meaning and integrity that their fractured imagination has denied them. But my earlier warning of the potential dangers for the unstable and unwary when navigating the partial dissolution of the protective Self to accommodate the creative Thou, inherent in the creative process, should give us pause. The therapist/teacher will need more than their art to guarantee the sufferer's safe passage. What does it mean to be with the other in their agon of creativity?

I make no other claim: for example, the sufferers may not become steady and dependable citizens, parents or key workers. Their claim to stability and responsibility may not extend much beyond the protected realm of their art. Perhaps it might: there is no reason I can think of as to why it should. What does seem clear, however, is that the quality of their personal life could be radically transformed, and they might begin to temper grief with joy and fear with love within the holy alliance with their teacher/therapist. Here would be a reformation driven from within rather than from without. As such it might have a fair chance of success. But we must make no mistake: the neonate artist engages and wrestles with powerful forces, must be strong enough to take risks and endure protracted periods in a cognitive wilderness, waiting for answers to the questions posed by her making. Nothing is more serious or less neutral than art; nothing demands greater honesty and integrity. The artist is not an illusionist, 
isn't joking, means exactly what she says and believes absolutely in what she does. She looks you straight in the eye to see if you will return her gaze. The snake she charms from the basket is real and deadly for all its sinuous beauty. But when it dances, she will bless it.

\section{I and Thou}

Life begins with the imperative that the world should service ME; I then issue the imperative of "I command you to heed my will"; in the reflexive creative act of the adult I surprise myself as THOU; in confronting my materials with my Thou (for which to happen I must abandon my I) I convert them into a medium with whom I can have a conversation, moving from childhood into adulthood, opening the possibilities of mature intimate relationships.

Essentially this means, following Coleridge, the dissolution (or suspension) of the sceptical Self to make room for the believing Thou as its unique, coeval partner in the process of concinnity: the harmonizing of dissonant elements, the graceful bringing together of subject and object. Discovering the power intrinsic to suspension within the potential space, the artist finds a new, reflexive dynamic of engaging with the world, in suspension between playing and reality. The Gravity of the work lies in the unreserved surrender of the artist's I, to the concinnity of the Thou, which is to say, to Grace. The dread, the duende, the pity and the terror arise from being in the presence of the dissolution of the one and the birth of the other-a life-transforming moment perhaps: she herself becomes the vanishing point of her own re-making, for only in her vanishing shall the work finally be realized, where the real work is herself, whole, composed and beautiful. Can you watch over another's agon? Can you minster to her metamorphosis?

\section{Bibliography}

Armstrong R. (1976). Wellspring: On the Myth and Source of Culture, Cambridge: Cambridge University Press.

Coleridge S. (2014). Biographia Literaria, Edinburgh: Edinburgh University Press. 
Collingwood R.G. (2013). The Principles of Art, Oxford: Oxford University Press

MacLeish A. (1984). Arts Poetica in Collected Poems, New York: Houghton Mifflin.

Ross M. (2011). Cultivating the Arts in Education and Therapy, Abingdon: Routledge.

Thomas D. (2003). Collected Poems, London: Everyman Editions.

Weil S. (2001). Gravity and Grace, Abingdon: Routledge.

Winnicott D. (2005). Playing and Reality, Abingdon: Routledge.

Witkin R. (1974). The Intelligence of Feeling, London: Heinemann Educational Books.

Wordsworth W. (1994). Collected Poems, London: Wordsworth Poetry Library.

\section{ADDRESS FOR CORRESPONDENCE}

\section{Malcolm Ross}

Emeritus Professor

University of Wolverhampton

e-mail: su7097@eclipse.co.uk 